\title{
Nexus between relationship marketing and export performance of readymade garments exporting firms
}

DOI: $10.35530 / I T .072 .06 .202028$

KHALID JAMIL

MUHAMMAD WAQAS RANA

DUNNAN LIU

FIZA AMJAD

ALIYA ANWAR

MINGGUANG LIU

\begin{abstract}
REZUMAT
Nexus between relationship marketing and export performance of readymade garments exporting firms

The aim of this study to find out the impact of relationship marketing on export performance in readymade garments exporting firms of Pakistan. There is also the aim to find the mediating impact of trust between the relationship of relationship marketing and export performance. The present study aims to fill the existing gap in the literature which has been neglected in the previous studies. Data was collected from the managerial staff of readymade garments exporting firms and apply multiple linear regression. After the analysis of collected data, it was found that all the components of relationship marketing used in the study have positive and significant impact on export performance. It was also found that trust partially mediated the relationship of relationship marketing and export performance. At the end researchers recommended that this model can be used with more mediators and enhancing the sample size. It was also recommended to the management of exporting firms that they should more emphasize on trust to improve its export performance to different countries.
\end{abstract}

Keywords: relationship marketing, adaptation, communication, cooperation, export performance, readymade garments

Legătura dintre marketingul relațional și performanța la export a firmelor exportatoare de articole de îmbrăcăminte

Scopul acestui studiu este de a afla impactul marketingului relațional asupra performanței la export în cazul firmelor exportatoare de articole de îmbrăcăminte din Pakistan. De asemenea, scopul lucrării este de a găsi impactul de mediere al încrederii între relația dintre marketingul relațional și performanța la export. Prezentul studiu iș̦i propune să umple golul existent în literatură, care a fost neglijat în studiile anterioare. Datele au fost colectate de la personalul managerial al firmelor exportatoare de articole de îmbrăcăminte și au fost aplicate regresii liniare multiple. În urma analizei datelor colectate, s-a constatat că toate componentele de marketing relațional utilizate în studiu au un impact pozitiv și semnificativ asupra performanței la export. De asemenea, s-a constatat că încrederea a mediat parțial relația dintre marketingul relațional și performanța la export. La final, cercetătorii au recomandat că acest model poate fi utilizat cu mai mulți mediatori și mărirea dimensiunii eșantionului. De asemenea, s-a recomandat managementului firmelor exportatoare să pună mai mult accent pe încredere pentru a-și îmbunătăți performanța la export în diferite țări.

Cuvinte-cheie: marketing relațional, adaptare, comunicare, cooperare, performanță la export, articole de îmbrăcăminte

\section{INTRODUCTION}

Textiles and clothing industry are two very vital components of the economy and contribute a significant volume in Pakistan's economy. It accumulates $46 \%$ of the total industrial production and $67 \%$ of exports. Being one of the primary sectors as Pakistan is an agriculture intensive country, it employs $40 \%$ of the country's population and supplements $10.20 \%$ to the gross domestic product. In the near past, Pakistan was once one of the top five largest row cotton-producing countries in the world but sadly exported in minimal quantity to foreign markets. The reasons for fewer exports to other counties involve high-Cost of production, Sami-skilled and semi-trained employees, technological challenges, lack of the management vision, and lack of modernization of specialized machinery. The rising cost of production plays a significant role in the development of the value chain in global markets. Nevertheless, in the face of a recent shift in foreign markets and changing developments, Pakistan has tremendous export capacity. However, Pakistan's textiles sector needs to establish efficient manufacturing processes and cost to draw long-term buyers on foreign markets to remain competitive in global markets (Garment Industry report of Pakistan, 2017).

There was an intense economic competition between globalization and the dynamic world markets. Exports have therefore been extremely necessary not just for firm development but also for survival. The key form of internationalization for businesses is export. Exports have always been important to policymakers in terms of the allocation of international capital, work growth, and development [1]. Therefore, scholars and practitioners have gained significant attention in the fields of international marketing, production, and 
assessment of export performance. Many studies studied a range of different determinants of export performance [2]. Traditional indicators, including management, market, and environmental factors, have contributed to the success of exports.

Nonetheless, cooperation with market growth and enhanced competition became increasingly important, and trade ties have become the central concept of the development and preservation of export ties [3]. Throughout the developing sector, scientists have paid close attention to the factors and consequences of marketing relationships. Effective communication is limited since helping an established client is simpler than recruiting new clients [4]. Improved collaborations to show beneficial results are the foundation for similar study outcomes [5]. Rambocas et al. [5] noted the mediation impact on customer satisfaction of the aspects of operation and goods of the company relationship, but this was focused on evidence from both the industry and consumer industries. The problem arises, however, how the aspects of the corporate relationship contributing to strong customer satisfaction vary between the service industry and the manufacturing sector. Various forms of customer loyalty (i.e., attitudinal loyalty and behavioural loyalty) are expected to emerge from different aspects of company relationships. Limited exposure has been given to shifts in linkages between measurements in various partnership times, the presence of which has been suggested by Rambocas et al. [5] through corporate research surveys, confidence has been found to have beneficial effects on customer partnerships. It is considered to be an asset in the measurement of partnership efficiency. It analysed the various viewpoints of the business relationship aspects (i.e., commitment-interest, reliance, transaction cost economics, and relational norms) and showed that confidence, loyalty, and relationship-specific expenditure were core drivers of business relationship success. Diamantopoulos and Winklhofer [6] defined dedication as a particular contribution or feedback into a partnership and introduced three distinct principles of engagement, attitudinal or relational dedication, functional commitment, and temporal dedication. The first is based on expectations, and the second is focused on real inputs. Short engagement implies that the partnership can continue over time. In a meta-analysis of the empirical studies on this topic, Leonidou et al. [7] also found a positive relationship with performance. International business literature marketing ties, especially consumer internationalization policies and export knowledge, were extensively analysed and recorded [8]. The central principle of link marketing lies in the complicated and dynamic phase of internationalization of companies. Businesses, in particular those with low resources and experience, are looking for how to navigate this competitive environment in their early stage of internationalization. The usage of marketing partnership asymmetry is also essential to exporters in a general sense in order to minimize risks and increase the performance on the export market. The beneficial effect on the export success of partnership marketing as demonstrated by extensive scientific data [9].

Current theories of export actions have indicated that internationalization will take place in phases. This method indicates that companies, particularly those with capital constraints such as small and mediumsized businesses, are slowly internationalizing, first reacting to unsolicited demands, and then experimentally exporting to physically adjacent markets to become daily exporters, then entering geographically distant markets or adopting higher entry modes. These extensions are usually defined by the wealth of companies, including experiential expertise and networks. The advent of the foreign entrepreneurship viewpoint subsequently put greater focus on the position of businesses and their capacity to push international activities. Many reports also established a shortage of internal and external capital as one of the key factors that hampered firms' success in global markets [10]. This capital constraint can be more constraining to international success as companies are subject to global business entry-related sunk costs [11]. Sunk costs can, however, influence the regularity of exports also differently. Connections have various impacts on business performance [12]. Enterprises are entering into deeper alliances that lead that better long-term interaction with their customers. Communications often play a significant role in ensuring that customers support businesses and boost their competitive advantage.

Although literature offers a wide spectrum of shared expertise, there is only a limited effect on the export success and its management implications. Generally, their immediate outcomes for export development are calculated by quantitative variables. After media models inquiries [13], numerous experiments have been performed that analyse the mediate effect of interaction variables. No agreement was achieved on variables relevant to export production. Established organizations can promote disruptive enterprise and some more severe types of unproductive entrepreneurship.

By contrast, a significant proportion of literature study was performed in the West, and work was performed in developed or mixed countries. The determiners of export success in developed world firms have also been barely discussed while the market circumstances and management characteristics of the businesses differ from the industrialized worlds.

Moreover, marketing relations between countries in developing markets are far more effective than in the USA [14]. To this end, we have looked at Pakistani prepared textile companies exporting to Europe, an exciting area not yet addressed that is more important for emerging markets. Investment and exports in emerging economies have increased, especially in Europe. Growing business relationships is important in Asian communities. Thus, understanding the role of relational variables in export success in developing countries is extremely significant. The goal of this survey is to resolve these gaps by developing and 
testing a model that assesses the effect of export performance variables on developed countries.

\section{LITERATURE REVIEW AND HYPOTHESIS DEVELOPMENT}

The definition of the building has not been widely accepted [15], despite the number of studies concerned with the export outcomes. Foreign markets have become more feasible and desirable targets for growth-focused domestic businesses through globalization and innovation. Export marketing policy, management, and other information in the business, sector, commodity, and export demand are among the main performance factors strongly illuminated. Older reports viewed exports purely as a means of meeting the company's economic objectives. Sales or profits have been measured with no deliberate intention to link performance to the strategic and competitive objectives of an enterprise, for example, gaining footholds in foreign markets and neutralizing competitive pressure on the company in the domestic market. Besides, these studies have shown that export output is specifically influenced by the factors business, commodity, sector, and export demand. It was not stressed the central position of the constructive marketing strategy in deciding export efficiency. As a result, exporting research is more and more isolated, and the research consists of an autonomous "mosaic". The dynamic structure is widely accepted that test preference relies on context, in particular, how the research is performed, its precision, and the viewer's goal [16]. Their preference for measurements is dependent upon qualitative criteria. Sousa [17] acknowledged that the export success requirements could be separated into objective and arbitrary metrics in a systematic literature review. Eleven are quantitative, and thirty nine are subjective among the 50 metrics for results. The outcomes of the latest investigation of both objective and subjective metrics of progress were reliable. Sousa [17] also spoke about a variety of explanations why academics prefer to use subjective rather than quantitative steps. Shoham [18], for his part, took another step by recommending the use of various indicators for better results. Katsikeas et al. [19] have carried out a thorough review of this subject in order to analyse and evaluate over 100 papers in the associated empirical studies. The analysis of its key determinants is another important research path for the field of export performance. For instance, a detailed model would be built to show potential comparative advantages, the usage of marketing methodologies, and the contribution to exports. In the same way, Morgan et al. [20] suggested an integrative theory that provides empirical support to a variety of past export projects.

Marketing partnerships have a wide range of components. The variables were grouped mainly in two categories: relational (adapting, cooperation, communication) and relational (trust and commitment) contextual variables. We present in this study a model in which output variables relate to the results of the partnership. Trust is the biggest goal to be obtained by businesses and is key to growth. We were assured that the partnership literature is recognized as a significant framework [3]. Such factors typically have long-lasting impacts on businesses and are built over time. We also included them in our definition as mediators. Our first hypothesis is the trust effect on a willingness to rely on an exchange partner that has faith in context variables. Zou et al. [21] announced that confidence takes place whenever a party values its interchange partner integrity and dignity. Within this portion, we establish a sub-hypothesis about the effect of the background variable.

$H_{1}$ : Relationship Marketing has significant impact on Trust

The emphasis on adaptation is on reacting and modifying products, processes, and solutions to these demands from the organization. The market climate recently shifted drastically, making it extremely necessary for businesses to survive and to respond to consumer shifts. While it focuses on the alteration of material, it can be changed in other sectors, including meat, electronics, etc. This sends a warning to a friend that in an international world of multiple discrepancies and unease, a strong and especially significant institution remains [22]. Effective versatility allows corporations to establish more intimate partnerships with their customers. However, work on the change of outcomes is inconsistent. The findings from d-detriment and marginal effects have had a substantial influence. However, adaptation is seen as a cornerstone of confidence [23]. While deciding, the consumer depends more on the retailer, which is pricey. Adaptation needs energy and commitment, giving a message of confidence. In short, adaptation helps develop partners' trust.

\section{$H_{1 a}$ : Adaptation has significant impact on Trust}

Cooperation is the second dimension of our philosophical systemic study. Organizations function together to enhance their performance in an increasingly competitive society. Cooperation is a process in which couples operate together to accomplish shared goals. Cooperation establishes alliances between organizations for mutual purposes. The mutual relationship is part of the sharing and preservation of knowledge [24]. It strengthens coordination between the groups. Innovatively as through success expectations, teamwork also improves business income. If partners cooperate more, they know more about each other. This is a challenge to trust, knowledge asymmetry. Confidence and collaboration were then formed. Amjad et al. [25] study identified a significant shift in partners' commitment and confidence. Contrary to the partnership which encourages trustbased cooperation, more research is needed because it is not quite obvious how such variables affect each other. We assume that establishing confidence requires more time than opening up collaboration. We, therefore, propose confidence as a variable relation result dependent on the partnership, since collaboration among partners helps companies to 
know each other better, and it is important to create trust between businesses:

$H_{1 b}$ : Cooperation has significant impact on Trust

The connection is also a history that is regarded as important for the development and sustainability of relationships. The act of sending a message to another party is described as human action in order to communicate the message meaningfully [26]. Throughout all relationships, cooperation is essential in that it facilitates the sharing of information and dispute resolution. She has also served as a trustee delegate. Knowledge asymmetry poses a challenge in the export partnership since participants with different contexts are usually at risk of acting opportunistically. It is dangerous to create confidence if couples do not learn much about each other. Partners know each other's goals, tools, and expertise by good contact. This increasing asymmetry and vulnerability to knowledge lead to increased trust.

$H_{1 c}$ : Communication has significant impact on Trust Confidence for exporting businesses is critical in the foreign business setting, despite the volatility and confusion. The domestic industry is more dynamic, more competitive, and significant for the analysis of international firms, compared to internal links with varying levels that affect confidence between parties [27]. Scientists in this area have become rather sensitive to trust and a critical part of the process of Uppsala internationalization. Exporters are confronted by a sense of knowledge asymmetry and opportunism, and trust is one form of mitigating such menaces. The opportunity to track and control opportunistic activities decreases partner trust, which improves partners' engagement and decreases the frequency of distress. Via faith-builders, contracts such as large-scale administrative recruiting are reduced [28]; an organization can take more risk in selling relationships with a strong degree of trust. Confidence also improves the exchange of information among partners. We suggest a positive impact on export production in each of these statements.

$\mathrm{H}_{2}$ : Trust has significant impact on Export Performance Literature extensively researched marketing relationships, with collaborations identified as key business resources in many studies. Relations like responsiveness, contact, engagement, trust, and teamwork are analysed according to their effect on the company's results, and some studies take the findings implicitly rather than explicitly into consideration. Models of faith and devotion were developed by Sarfraz et al. [30] as intermediaries, but not always partnership variables. Nonetheless, the research does not settle about how relationship factors are transferred. As previously stated, we try a comprehensive model where trust and commitment are the key mediators in partnership marketing and, as we suggest, display the export results as follows.

Confidence is a key factor in export production, as stated in the previous section. Organizations want their spouses to have some sort of partnership. Some variables in the connection context, such as openness, cooperation, and collaboration, resulting in confidence formation between partners and organizations, whereas reduced costs and synergies are significantly improved my confidence. Several researchers have shown confidence as a mediator in relationships of commitment and cooperation, while others say confidence leads to commitment [31]. In summary, the trust position is seen in combination with export performance.

The central issue is an organization's perception of potential partner activities and the partner's conduct. This belief comes from multiple ways of information exchange and relationship. They assume that tolerance, teamwork, and coordination relate to the confidence-building variables. When partners, there is no deception, and confidence is built up as a response to these relational variables [32]. So, we say that trust is driven by specific contextual variables and has a positive impact on export success:

$\mathrm{H}_{3}$ : Trust mediates the relationship of Relationship Marketing and Export Performance

$H_{3 a}$ : Trust mediates the relationship of Adaptation and Export Performance

$\mathrm{H}_{3 b}$ : Trust mediates the relationship of Cooperation and Export Performance

$\mathrm{H}_{3 \mathrm{c}}$ : Trust mediates the relationship of Communication and Export Performance

\section{MATERIALS AND METHODS}

Current study was conducted in Pakistan because readymade garments export is one of the largest export sectors of the country. This research is quantitative in nature and a well-structured adapted questionnaire was designed to collect the primary data from managerial level staff of those firms which are exporting readymade garments to different countries. The selection of firm is based on criteria that it should have more than fifty employees. Questionnaires were sent to managers of the firms through electronic mail and asked them to fill these questionnaires within two weeks. Two hundred questionnaires were delivered to the managers of those firms which fulfil our criteria. After two weeks 190 questionnaires were received from which fifteen questionnaires found incomplete and excluded from final sample. After this, 175 valid and complete responses were added for analysis. Response of the respondents was judged on fivepoint Likert scale which was consist 1 for strongly disagree and 5 for strongly agree. The items of the questionnaire were already used and having strong reliabilities in context of Pakistan as well as other countries, sources of these items are mentioned in table 1. For the purpose of data analysis Statistical Package for the Social Sciences (SPSS) have been used.

\section{RESULTS}

To check the relationship adaptation, communication and cooperation on export performance multiple linear regression was performed. After the analysis it 
MEASURES USED FROM EXISTING STUDIES

\begin{tabular}{|c|c|c|c|c|}
\hline $\begin{array}{c}\text { Sr. } \\
\text { no. }\end{array}$ & Construct & Items & Reference & $\begin{array}{c}\text { Cronbach's } \\
\boldsymbol{\alpha}\end{array}$ \\
\hline 1 & Adaptation & 5 & {$[13]$} & 0.80 \\
\hline 2 & Communication & 4 & {$[18]$} & 0.90 \\
\hline 3 & Cooperation & 6 & {$[24]$} & 0.87 \\
\hline 4 & Trust & 6 & {$[25]$} & 0.85 \\
\hline 5 & $\begin{array}{c}\text { Export } \\
\text { Performance }\end{array}$ & 4 & {$[27]$} & 0.81 \\
\hline
\end{tabular}

was found that the model was significant as $(p<0.01)$ and the value of F-statistics is 59.90 . The coefficient of determinants $\left(R^{2}\right)$ value is 0.478 which shows that $47.8 \%$ change in export performance is due to these three independent variables (Adaptation, Communication, Cooperation) rest of change may be due to other variables which are not included in the model (table 2).

Furthermore, the results of multiple linear regression show that all three variables have significant and positive impact on dependent variable as $p<0.05$.

Table 2

\begin{tabular}{|c|c|}
\hline \multicolumn{2}{|c|}{ REGRESSION RESULTS } \\
\hline Model Variable & Standardized $\boldsymbol{\beta}$ \\
\hline Adaptation & $0.333^{* *}$ \\
\hline Communication & $0.303^{* *}$ \\
\hline Cooperation & $0.395^{* *}$ \\
\hline Trust & $0.414^{* *}$ \\
\hline $\mathrm{F}$ & $59.90^{* *}$ \\
\hline $\mathrm{R}^{2}$ & 0.478 \\
\hline Adjusted $\mathrm{R}^{2}$ & 0.472 \\
\hline
\end{tabular}

The standardized coefficient $(\beta)$ for each independent variable is adaptation (0.333), communication (0.303) and cooperation (0.395) show that all independent variables have positive and significant impact on export performance.

\section{MEDIATION ANALYSIS}

Mediation analysis has been performed to check the mediation effect of trust between independent variables (adaptation, communication, and cooperation) and the dependent variable (export performance). Analysis shows that total effect $(0.362)$ with direct effect (0.339) and indirect effect is (0.313) of independent variable adaptation and dependent variable export performance while trust mediates their relationship along with $(p<0.05)$. Between lower confidence level and upper confidence level there is no zero exists so it confirms that trust mediates the relationship of adaptation and expert performance (table 3). Sobel's test value $(z=5.05)$ also confirms the mediation. Similar results also present that trust mediates the relationship of communication and export performance and Sobel's test also confirms mediation $(z=5.27)$ and trust also mediates the relationship of cooperation and export performance $(z=4.97)$.

\section{DISCUSSION AND CONCLUSION}

The main purpose of current study is to find the impact of relationship marketing on exporting performance of readymade garments exporting firms of Pakistan. Additionally, the mediating role of trust is also under the consideration. Findings of the study revealed that all the hypotheses found positive and significant to which shows the relationship of variables.

First, under sight study shows the relationship between adaptation and trust in the context of Pakistani textile readymade garments exporting

Table 3

\begin{tabular}{|c|c|c|c|c|c|}
\hline \multicolumn{6}{|c|}{ MEDIATING EFFECT } \\
\hline Adaptation $\rightarrow$ Trust $\rightarrow$ Export Performance & Effect & L.C.L & U.C.L & S.E & $\mathbf{P}$ \\
\hline Total effect & 0.362 & 0.307 & 0.455 & 0.041 & 0.000 \\
\hline Direct effect & 0.339 & 0.311 & 0.540 & 0.033 & 0.000 \\
\hline Indirect effect & 0.313 & 0.310 & 0.415 & 0.023 & - \\
\hline \multicolumn{6}{|c|}{ Sobel's Test Z = 5.05} \\
\hline \multicolumn{6}{|l|}{ Communication $\rightarrow$ Trust $\rightarrow$ Export Performance } \\
\hline Total effect & 0.532 & 0.439 & 0.369 & 0.051 & 0.000 \\
\hline Direct effect & 0.327 & 0.274 & 0.465 & 0.047 & 0.000 \\
\hline Indirect effect & 0.353 & 0.583 & 0.362 & 0.045 & - \\
\hline \multicolumn{6}{|c|}{ Sobel's Test $Z=5.75$} \\
\hline \multicolumn{6}{|l|}{ Cooperation $\rightarrow$ Trust $\rightarrow$ Export Performance } \\
\hline Total effect & 0.342 & 0.439 & 0.541 & 0.033 & 0.000 \\
\hline Direct effect & 0.256 & 0.292 & 0.432 & 0.028 & 0.000 \\
\hline Indirect effect & 0.339 & 0.342 & 0.307 & 0.057 & - \\
\hline \multicolumn{6}{|c|}{ Sobel's Test $Z=4.97$} \\
\hline
\end{tabular}


firms. After analysing it was found that the impact of adaptation on trust is positive and significant. Results of this study are also supported by the results of previous study which was conducted by Shoham [18]. Results explain that adaptation is very important component to develop trust when a firm is exports garments to different countries. Hence, trust leads to enhance the export performance of the firm.

Second, the purpose of this study is to find the relationship between communication and trust in the readymade garments exporting firms of Pakistan. Results of the study express that communication plays a vital role to develop the trust of the customers. Similar findings were also presented by Mattoussi and Ayadi [11] previously in their study. These results prove that better communication to the clients leads to develop trust towards firm and this trust helps to improve the export performance of that firm. An exporting firm should communicate with its clients in proper way so that firm can get long term benefits and enhance its performance in exporting of readymade garments.

Third, this study examines the role of cooperation to develop trust in the readymade garments exporting firms in Pakistan. Similar results were also presented by Lengler et al. [13] Earlier in their studies.

Cooperation is much more element to develop and enhance the trust level of clients the exporting firms as the clients look for better and quick cooperation from the firms. So, firms should be more cooperative and dynamic when they are exporting its products especially the readymade garments.

Fourth, the aim of this study is to analyse the mediating role of trust between adaptation, communication and cooperation. Outcomes of this study show that trust partially mediates the relationship of these three elements of relationship marketing. These results are supported with the findings of Dunnan et al. [22] previously they also presented similar results in their studies. Along with the relationship marketing it is more important to develop trust firm from the clients which will leads to enhance the export performance of the firms in the field of readymade garments.

\section{LIMITATIONS AND FUTURE RESEARCH}

This study has many valuable contributions in the current literature. Along with the contributions there are also some limitations of the study which are necessary to discuss here. First of all, the sample size of the present research is low and is limited up to the export of readymade garments only so it does not show the overall picture of export sector. Secondly this research is based on empirical nature and the authors of this research are full time scholars so it is not possible for them to spend a huge time to collect data by visiting one by respondent. So, the lack of time and resources there are possibilities that respondents may not fill the questionnaires by full attention. Despite the contributions of this study into the existing literature there are many aspects yet to discuss for future studies so that the deficiencies in the literature can be covered. Future researchers can be enhancing the sample size and it can be applied other sectors irrespective of textile sector.

Furthermore, it can be added another mediating variable like commitment to measure relationship marketing and its impact on export performance.

\section{ACKNOWLEDGEMENT}

This paper is partly supported by "National Social Science Foundation of China (No. 19ZDA081).

\section{REFERENCES}

[1] Hultman, M., Robson, M.J., Katsikeas, C.S., Export product strategy fit and performance: An empirical investigation, In: Journal of International Marketing, 2009, 17, 4, 1-23

[2] Shi, X., Xu, Z., Environmental regulation and firm exports: Evidence from the eleventh Five-Year Plan in China, In: Journal of Environmental Economics and Management, 2018. 89, 187-200

[3] Samiee, S., Chabowski, B.R., Hult, G.T.M., International relationship marketing: Intellectual foundations and avenues for further research, In: Journal of International Marketing, 2015, 23, 4, 1-21

[4] Gul, R.F., Liu, D., Jamil, K., Baig, S.A., Awan, F.H., Liu, M., Linkages between market orientation and brand performance with positioning strategies of significant fashion apparels in Pakistan, In: Fashion and Textiles, 2021, $8,1,1-19$

[5] Rambocas, M., Meneses, R., Monteiro, C., Brito, P.Q., Direct or indirect channel structures. Evaluating the impact of channel governance structure on export performance, In: International Business Review, 2015, 24, 1, 124-132

[6] Diamantopoulos, A., Winklhofer, H., Export sales forecasting by UK firms: Technique utilization and impact on forecast accuracy, In: Journal of Business Research, 2003, 56, 1), 45-54

[7] Leonidou, L.C., Fotiadis, T.A., Christodoulides, P., Spyropoulou, S., Katsikeas, C.S., Environmentally friendly export business strategy: Its determinants and effects on competitive advantage and performance, In: International Business Review, 2015, 24, 5, 798-811

[8] Fernández-Mesa, A., Alegre, J., Entrepreneurial orientation and export intensity: Examining the interplay of organizational learning and innovation, In: International Business Review, 2015, 24, 1, 148-156

[9] Jamil, K., Hussain, Z., Gul, R.F., Shahzad, M.A., Zubair, A., The effect of consumer self-confidence on information search and share intention, In: Information Discovery and Delivery, 2021, https://doi.org/10.1108/IDD-12-2020-0155

[10] He, X., Brouthers, K.D., Filatotchev, I., Market orientation and export performance: the moderation of channel and institutional distance, In: International Marketing Review, 2018, 35, 2, 258-279

[11] Mattoussi, W., Ayadi, M., The dynamics of exporting and innovation: Evidence from the Tunisian manufacturing sector, In: Journal of African Economies, 2017, 26, 1, 52-66 
[12] Jamil, K., Liu, D., Gul, R.F., Hussain, Z., Mohsin, M., Qin, G., Khan, F.U., Do remittance and renewable energy affect CO2 emissions? An empirical evidence from selected G-20 countries, In: Energy \& Environment, 2021, 0958305X211029636

[13] Lengler, J.F., Sousa, C.M., Marques, C., Examining the relationship between market orientation and export performance: The moderating role of competitive intensity', International Marketing in Rapidly Changing Environments, In: Advances in International Marketing, 2018, 24

[14] Kozlenkova, I.V., Samaha, S.A., Palmatier, R.W., Resource-based theory in marketing, In: Journal of the Academy of Marketing Science, 2014, 42, 1, 1-21

[15] Julian, C.C., Export marketing performance: a study of Thailand firms, In: Journal of small business management, 2003, 41, 2, 213-221

[16] Naseem, S., Mohsin, M., Hui, W., Liyan, G., Penglai, K., The investor psychology and stock market behavior during the initial era of COVID-19: a study of China, Japan, and the United States, In: Frontiers in Psychology, 2021, 12, 16

[17] Sousa, C.M., Export performance measurement: an evaluation of the empirical research in the literature, In: Academy of Marketing Science Review, 2004, 1

[18] Shoham, A. Export performance: a conceptualization and empirical assessment, In: Journal of international Marketing, 1998, 6, 3, 59-81

[19] Katsikeas, C.S., Leonidou, L.C., Morgan, N.A., Firm-level export performance assessment: review, evaluation, and development, In: Journal of the Academy of Marketing Science, 2000, 28, 4, 493-511

[20] Morgan, N.A., Kaleka, A., Katsikeas, C.S., Antecedents of export venture performance: $A$ theoretical model and empirical assessment, In: Journal of Marketing, 2004, 68, 1, 90-108

[21] Zou, S., Fang, E., Zhao, S., The effect of export marketing capabilities on export performance: an investigation of Chinese exporters, In: Journal of International Marketing, 2003, 11, 4, 32-55

[22] Dunnan, L., Jamil, K., Abrar, U., Ali, S., Awan, F.H., Ali, S., Digital Generators and Consumers Buying Behavior, In: 3rd International Conference on Computing, Mathematics and Engineering Technologies (iCoMET), IEEE, 2020, 1-5

[23] Naseem, S., Fu, G.L., Mohsin, M., Rehman, M.Z.U., Baig, S.A., Semi-Quantitative Environmental Impact Assessment of Khewra Salt Mine of Pakistan: an Application of Mathematical Approach of Environmental Sustainability, In: Mining, Metallurgy \& Exploration, 2020, 37, 1185-1196

[24] Montossi, F., Cazzuli, F., Brito, G., Realini, C., Luzardo, S., Rovira, P., Font-i-Furnols, M., The challenges of aligning consumer preferences and production systems: Analysing the case of a small beef meat exporting country, In: International Journal of Agricultural Policy and Research, 2018, 6, 9, 144-159

[25] Amjad, F., Baig, S.A., Jamil, K., Amjad, A., Impact of service quality on Loyalty \& Mediating role of Trust: An empirical investigation of Restaurants, In: Journal of Education and Vocational Research, 2017, 8, 4, 6-14

[26] Mohsin, M., Zhu, Q., Naseem, S., Sarfraz, M., Ivascu, L., Mining Industry Impact on Environmental Sustainability, Economic Growth, Social Interaction, and Public Health: An Application of Semi-Quantitative Mathematical Approach, In: Processes, 2021, 9, 6, 972

[27] Naseem, S., Fu, G.L., Mohsin, M., Aunjam, M.S., Rafiq, M.Z., Jamil, K., Salamat, S., Development of an inexpensive functional textile product by applying accounting cost benefit analysis, In: Industria Textila, 2020, 71, 1, 17-22, http://doi.org/10.35530/IT.071.01.1692

[28] Ismail, D., Alam, S.S., Trust, commitment, and competitive advantage in export performance of SMEs, In: Gadjah Mada International Journal of Business, 2017, 19, 1, 1

[29] Hasaballah, A.H.A., Genc, O.F., Mohamad, O.B., Ahmed, Z.U., How do relational variables affect export performance? Evidence from Malaysian exporters, In: Asia Pacific Journal of Marketing and Logistics, 2019, https://doi.org/10.1108/apjml-12-2017-0345

[30] Sarfraz, M., Mohsin, M., Naseem, S., Kumar, A., Modeling the relationship between carbon emissions and environmental sustainability during COVID-19: A new evidence from asymmetric ARDL cointegration approach, In: Environment, Development and Sustainability, 2021, 1-19.

[31] Bloemer, J., Pluymaekers, M., Odekerken, A., Trust and affective commitment as energizing forces for export performance, In: International Business Review, 2013, 22, 2, 363-380

[32] Baig, S.A., Rehman, M.Z.U., Naz, A., Jamil, K., High core self-evaluation maintains patient oriented behavior: A motivational model of reward system, In: Journal of Public Affairs, 2020, e2488.

\footnotetext{
Authors:

KHALID JAMIL ${ }^{1}$, DUNNAN LIU ${ }^{1,2}$, ALIYA ANWAR ${ }^{1}$, MUHAMMAD WAQAS RANA ${ }^{1}$ FIZAAMJAD ${ }^{3}$, MINGGUANG LIU1,2

${ }^{1}$ School of Economics and Management North China Electric Power University Beijing 102206, China e-mail: khalidjamil29@yahoo.com, liudunnan@163.com,mwaqas_001@hotmail.com, fiza.amjad1@hotmail.com, mingguangliu@163.com

${ }^{2}$ Beijing Key Laboratory of New Energy and Low-Carbon Development, North China Electric Power University, Beijing 102206, China

${ }^{3}$ Department of Business Administration, Central South University, China
}

\section{Corresponding author:}

ALIYA ANWAR

e-mail: aliyakhalid82@gmail.com 